\title{
A QUALITATIVE TEACHER-STUDENT ORIENTED APPROACH TO TRANSLATION TEACHING
}

\author{
Ali Almanna \\ Head of the Department, \\ English Language and Literature, \\ Al-Zahra College for Women, Oman
}

\author{
Hashim G. Lazim \\ Shatt Al-Arab University \\ College, Iraq
}

\begin{abstract}
This article proposes a move away from the traditional methodologies of teaching translation that focus on text-typologies to an eclectic teacher and student oriented approach that involves a set of interdisciplinary skills with a view to improving students' translation quality. Here, a combination of the minimalist approach, revision vs. editing and discourse analysis is the proposed alternative in translation teaching. This combination brings together both teacher-and student-centred approaches. As the validity of the approach proposed relies partially on instructors' competences and skills in teaching translation, universities, particularly in the Arab world, need to invest in recruiting expert practitioners instead of depending mainly on bilingual teachers to teach translation.
\end{abstract}

Keywords: translation teaching, minimalist approach, revision, editing \& discourse analysis.

\section{INTRODUCTION}

Translation, as an important human activity, has been practised from days immemorial. Teaching translation as a skill used to be mainly teacher-centred where only a very limited margin was left for students/learners to undertake the task of drilling it themselves, certainly with the help of the instructor. Besides that, translation teaching has been considerably based on the instructor's proficient language command. With the breakthroughs witnessed in different spheres of linguistic studies and other related disciplines, translation instructors nowadays need to be knowledgeable about various linguistic disciplines, such as discourse analysis, revision, editing, documentation, desktop publishing, etc. (Olvera-Lobo et al, 2005: 132). In this regard, Kingscott (1995: 295) holds that "university courses should not simply be practice-oriented. It is the role of universities to open up students' minds, not to tunnel them in a particular direction". Translating programmes therefore need to view translating as an 
activity which takes place within a social context and "should be based on a careful and up-to-date assessment of their multifaceted future profession" (Ulrych, 1995: 251). Further, those programmes need to "cater for client-related skills since a significant part of translators' future professional lives" depend partially on the amount of educational training they receive, "whether they opt for in-house or freelance translating" (ibid.).

It is held in this paper that in parallel to 1) the traditional methodologies of translation teaching that focus on text-typologies and 2) training strategies that can develop professional informational skills, such as using the Internet and the like, attention needs to be paid to the tactics of teamwork cooperation. This is because it is felt that such team work will provide the student trainees with a beneficial learning experience that enhances their competences, be it translating competence, linguistic competence, communicative competence, cultural competence, research competence, etc. According to the EN-15038 European Quality Standard for Translation Services, paragraph 3.2.2 (2006: 7), a qualified translator should have the following competences:

a) Translating competence, i.e. "the ability to translate texts to the required level"; "it includes the ability to assess the problems of text comprehension and text production as well as the ability to render the target text [...] and to justify the results";

b) Linguistic and textual competence in the source language and the target language, i.e. "the ability to understand the source language and mastery of the target language"; Textual competence "requires knowledge of text type conventions for as wide a range of standard-language and specialized texts as possible";

c) Research competence, information acquisition and processing, i.e. it "requires experience in the use of research tools and the ability to develop suitable strategies for the efficient use of the information sources available";

d) Cultural competence, i.e. "the ability to make use of information on the locale, behavioural standards and value systems that characterize the source and target cultures"; and

e) Technical competence, i.e. "the abilities and skills required for professional preparation and production of translation", such as "the ability to operate technical resources".

Kiraly (2000) lays emphasis on the importance of encouraging student translators to team up as groups and work together confidently. This can be achieved when translation teaching is based on "authentic situated action, the collaborative construction of knowledge, and personal experience" (ibid: 3). In a similar vein, Al-Qinai (2011: 24) holds that "students' motivation increases tremendously if they are given authentic translation tasks which will eventually be published on the web or in any other media form". Further, 
the translation teachers prior to selecting or producing resources to their students need to figure out and analyze the student trainees' needs. This attunes well with Thornbury's (2006: 58) view that any course design should consist of a number of stages at the forefront of which come the learner's needs. The stages include:

a) identification and analysis of the learners' needs;

b) defining the overall objectives of the course in relation to the learners' needs;

c) syllabus design;

d) selecting or producing resources;

e) identifying the ways of testing learners at different stages of the course; and

f) evaluation which involves ways and procedures for evaluating the overall success of the learners.

In what follows, the researchers will touch on three different approaches that can be used in class with a view to improving the trainee translators' competences and skills - they are a minimalist approach, revision vs. editing and discourse analysis. Prior to this, the ultimate objective of the study, the main problem that the study tries to address and the methodology used in the study will be presented.

\section{OBJECTIVES \& METHODOLOGY}

The ultimate objective of this paper is to review the traditional methodologies of teaching translation that concentrate on text-typologies and, alternatively, proposes an eclectic multi-componential approach that involves a set of interdisciplinary skills with a view to improving the trainee translators' competences and skills. Since translation is multidisciplinary, translator training programmes need to cover not only proficient language command in both source- and target languages, but need to bring together knowledge and skills that belong to different disciplines, such as discourse analysis, revision, editing, documentation, desktop publishing and the like.

It is generally observed in teaching translation at the Department of Translation, College of Arts, University of Basrah, Iraq, that instructors play an almost exclusively key role in the teaching process except for few cases. As students practice translating texts prescribed by their instructors without recourse to other pertinent linguistic disciplines as props and motivation, their translation output therefore remains restricted and noncreative. Be that as it may, it is hypothesized in this paper that helping students to translate as cooperative teams instead of working individually, on the one hand, and acquainting them with the relevant disciplines to translation, such as 
discourse analysis, revision, editing, etc, on the other, would surely improve the translation process, and thus enhance their translation competence. To verify these assumptions, the researchers would undertake a test for fourthyear students of the Department of Translation, University of Basrah. Ten students were randomly chosen to render a short text entitled 'Uses of the Internet' from English into their own language, Arabic. Having implicitly informed the translator students of the translation purpose and the intended readership of the target text (TT) by stating that their translations will be published in one the local magazines, the researchers gave them one hour to finish translating the source text (ST). The students were allowed to use dictionaries. They were asked first to do their translations individually. Then, only a group of five students, who had already undertaken the individual translations, were asked to re-translate the same text collaboratively. It was felt that an empirical research design was most apt for such types of studies that attempt to

a) have new data or new information derived from the observation of data or from experimental work;

b) obtain solid evidence which supports or disconfirms hypotheses; or

c) generate new hypotheses or claims (cf. Williams and Chesterman, 2002: 58).

However, as there are three different approaches proposed in this study, namely a minimalist approach, revision vs. editing and discourse analysis, the aforementioned test was supported by a number of authentic examples taken from various translations done by different translators on different texts between Arabic and English.

\section{MINIMALIST APPROACH}

According to this approach, the trainee translators are asked to produce and select among different versions they produce by themselves. To put this differently, the trainee translator produces a number of drafts for the same source text, and then selects the most suitable draft among the drafts $\mathrm{s} /$ he has already produced. The aim of such an exercise for the trainee translators is to enhance their ability to create a variety of drafts for the same source text on the on hand, and to select among the drafts with justified confidence as quickly as they could. So, the emphasis is laid here on the elimination of the most preferable target text (Pym, 2003: 494).

Accordingly, it is a student-centred approach where the task of the teacher is kept to a minimum. Despite the fact that translation teachers have the right to produce their own versions and assess the student translators' versions, they should work, according to this approach, as coaches who do not interfere till a late stage on the one hand, and their training of the student translators should 
not be based on individualism of such assessment procedures on the other hand (ibid: 490).

By way of illustration, let us have a look at the following examples, translated first by individual students and then re-translated collectively by a group of student translators by adopting a minimalist approach:

\section{Discussion of the translation test:}

As stated in the previous section, ten fourth-year students of the Translation Department, College of Arts, University of Basrah were randomly chosen to translate a short text (around 100 words) entitled 'Uses of the Internet' from English into Arabic. They were given one hour to finish translating the text and were allowed to use dictionaries. They were asked first to translate the text individually.

The testees tried as hard as they can to be close to the ST. The theme of the text was preserved to a large extent. Yet, lack of experience and working under the pressure of time led to the following drawbacks:

a) Syntactic structures: The sentence 'The internethas brought a transformation in many aspects of life' has aroused some awkward understanding leading to disconcerted renditions as in the following two examples:

$$
\begin{aligned}
& \text { أ. رافق الأنترنت التحول في جميع أوجه الحياة. } \\
& \text { ب. الأنترنت قد بجلب التبديل أو التحويل للعديد من مظاهر الحياة. }
\end{aligned}
$$

Another example is the following rendering: 'Most people have computers in their homes, but even the ones who don't can always go to cyber cafes where this service is provided'.

$$
\begin{aligned}
& \text { كما أن أغلب الناس يمتلكون أجهزة الحاسوب في منازلهم ولكن كل شخص وبشكل تام أب }
\end{aligned}
$$

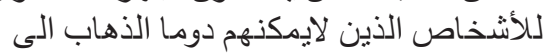

$$
\begin{aligned}
& \text { صدالات ذات التدكم الأتوماتيكي حيث أن هذه الخدمات الخدات تقدم. }
\end{aligned}
$$

The translated version definitely lacks cohesion and interrelatedness. One fragment of the sentence does not seem to give sense:

$$
\text { الأتومن كلنيكي ... }
$$

b) Wrong choice of equivalents: students' renderings project a number of examples on the erroneous use of equivalents. Some of these drawbacks are the result of 'fixed' words or phrases in the mind, such as قرية صغيرة (a global village). Other examples are shown in the following table: 


\begin{tabular}{|c|c|c|}
\hline ST & Students' renderings & acceptable renderings \\
\hline computer based & ـ ذ ذو قاعدة مبذية & بعتمد على الكمبيوتر \\
\hline interconnected & متواصلة & متصلة مع بعضهيا البعض \\
\hline may link & تتصدل & تربط \\
\hline introduced & انشأ & استخدم / وضدع موضع الاستخدام / ظهر \\
\hline access the internet & الأقتران بالأنترنت & استخدام الإنترنت \\
\hline aspects & مفاهيم & مظاهر / جوانب \\
\hline thousands & مئات & آلاف \\
\hline
\end{tabular}

c) Adding unnecessary words: Although student translators did not seem to overtranslate, their attempts reflected some lack of attentiveness during the translation process as in the following examples:

- '... in making the world into a global village'.

$$
\text { في جعل العالم داخل مدينة عالمية }
$$

- 'It is one of the biggest contributors in making the world into a global village'.

$$
\text { العالى الأغلب فأن الأنترنت هو واحد من أكبر المساهمات في تحويل }
$$

It is worth noting that the trainee translators do not have to resort to the minimalist approach when equivalents at the level of words, phrases, expressions or sometimes short sentences have been established. In order for "such an approach to work, it requires the presence of a problem and the generation of more than one rendition usually in a setting that involves a group of trainees" (Al-Qinai: 2011: 28).

\subsection{COLLABORATIVE TRANSLATION}

A group of five students, who had already undertaken the individual translations, were asked to re-translate the same text collaboratively. It is hypothesized here that teamwork would certainly conduce to an improved and more integrated translation resulting from exchanging of views and persuasive arguments. Given one hour for translation, the collaborative translated text that follows shows a noticeable improvement compared with the individual attempts referred to earlier.

\section{استخدامات الأنترنت}

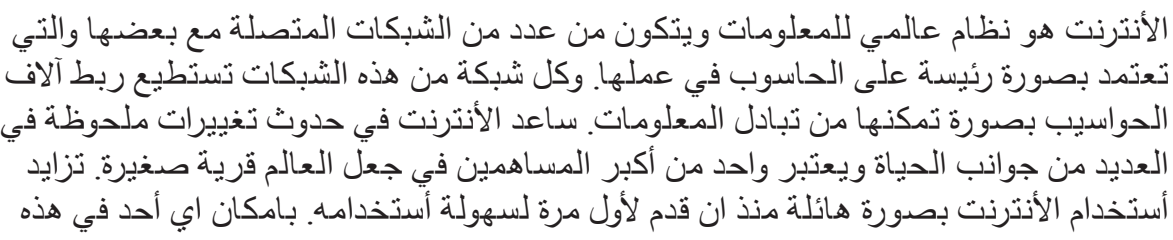


الأيام الأطلاع على الأنترنت ، معظم الناس يتصفحون الأنترنت في منازلهم وحتى أولئك الذئين

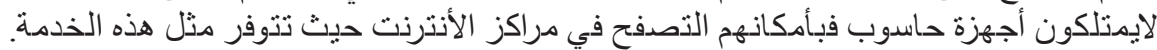

The TT here seems generally coherent and understandable. No apparent gaps in the text are diagnosed except for one place (preceding the last sentence). There are, however, a few lexical items which have been translated wrongly, such as

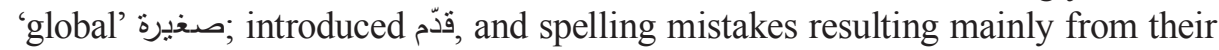

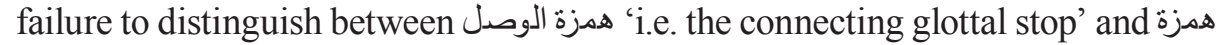

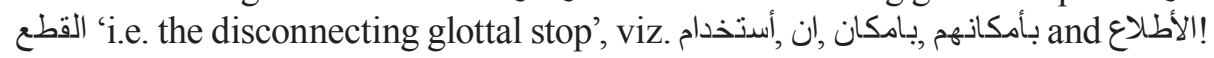

\section{REVISION VS EDITING}

In addition to the minimalist approach, another type of exercise needs to be activated in class, i.e. revision and editing. Prior to giving a detailed description of these processes, it is felt that a distinction needs be made between these two processes, i.e. revision and editing, and other related processes such as proofreading. To start with, revision "entails a professional, informed assessment of translation decisions and products. The process of revision is bi-directional and its purpose is to exert quality control" (Chackachiro, 2005: 225). He adds that such a process requires the assessor to

a) comprehend the content of the ST,

b) assess the process of translation and

c) be familiar "with the target-language culture, audience, and literature (in the broadest sense of the word)" (ibid.)

Revision is different from proof-reading and editing. Proof-readers normally busy themselves with language-related issues such as grammatical, syntactic, morphological, etc. and, at times, they pay attention to stylistic issues (for more details, see Almanna 2013: 130-136). By contrast, what concerns editors is how to achieve the "optimum orientation" of the proof-read and revised TT to live up to the target reader's expectations (Graham 1983: 104), by exploiting the lexical, syntactic and stylistic norms of the target language (TL) to the fullest (cf. Belhaaj 1998: 85). In this regard, Mossop (2007: 120) lists four criteria that should be taken into account by translation editors. They are posed in the form of questions that editors should ask themselves:

1) Are there some parts of the text which will not be of interest to the target readership?

2) Do several paragraphs have to be eliminated to make the text fit into the allotted space?

3) Is the writing lively and interesting? A translation may be accurate, idiomatic and authentic, but nevertheless make for rather dull reading.

4) Is the content appropriate to the genre? (Mossop, 2007: 120) 
In his list of criteria, in particular the first one, it seems that Mossop, "focusing on the translation of governmental papers to be used in the workings of institutions and departments, does not concern himself with literary texts" (Almanna, 2013: 134). As such, he does not account for the ethics of translation that "postulate that translation should signal the foreignness of the foreign text and create a readership that is more open to cultural differences" (Venuti, 1998: 87).

As such, there are two different approaches that a translation instructor can use in class, i.e. revision and editing. Revision as a tool for translation teaching can be conducted in different ways for example but not limited to:

a) the student provides his/her partner(s) with the source text that $\mathrm{s} / \mathrm{he}$ has already searched and prepared an ideal translation for;

b) the teacher provides his/her students with the same text or different texts and asks the students to act as revisers to classmates; and

c) the teacher provides his/her students with a bad translation and asks them to improve it.

Of course, here the student as a reviser should have access to the source text and should bring issues such as accuracy, completeness, readability and the like to the fore. It is worth mentioning that student translators' abilities and skills can well be sharpened if they are given roles as participants in the translation process. Further, the student reviser needs to justify his/her comments. Consider the following two representative examples:

\section{Example (1):}

\begin{tabular}{|c|c|}
\hline ST & $\begin{array}{l}\text { Use of the internet has grown tremendously since it was introduced. It is } \\
\text { mostly because of its flexibility. Nowadays one can access the internet } \\
\text { easily. }\end{array}$ \\
\hline TT & 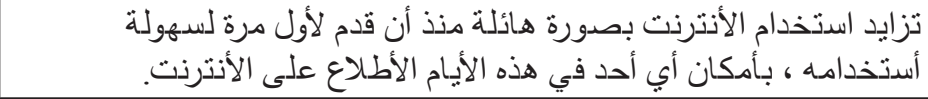 \\
\hline TT after revision & 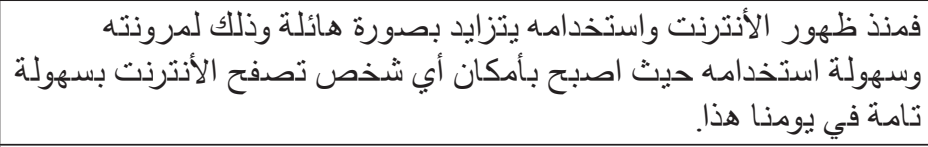 \\
\hline Justification & $\begin{array}{l}\text { Although the translation is generally good, there is lack of connectors } \\
\text { and coherence between ideas and sentences. }\end{array}$ \\
\hline
\end{tabular}

Example (2):

\begin{tabular}{|c|c|}
\hline ST & Only after it was privatized ... \\
\hline TT & وبعد أن ذقلت ملكيته \\
\hline TT after revision & وبعد أن خصخصدت ملكيته \\
\hline Justification & $\begin{array}{l}\text { This is an example of 'mistranslation' as the idea is not conveyed } \\
\text { properly. }\end{array}$ \\
\hline
\end{tabular}


With regard to editing, the trainee students as editors are required to shift their focus of attention, with the help of their course instructors, towards naturalness, i.e. well-formedness, acceptability, idiomaticity, authenticity, contemporaneity, intelligibility, accessibility, and readability (cf. As-Safi and Ash-Sharifi (1997: 60-61). They have to work on the TT without any access to the ST. Their task is confined to improving the TT to live up to the target readers' expectations. Such an exercise will help trainee students to develop a set of skills that would enable them to get rid of the constraints imposed on them by virtue of the ST per se. It is the responsibility of translation instructors to encourage their students at the beginning of the course to write as a TL writer would, taking into consideration the likely reading ability of the user of the TT. In other words, trainee students are encouraged to give full consideration to 'expectation norm', i.e. they need to take into account the TL grammaticality, acceptability, appropriateness and so on in a certain text type (Chesterman, 2000: 76). However, towards the end of the course, students' attention needs to be brought to the fact that there is an original text that needs to be analyzed, appreciated and reflected on in the TL, provided that this would not distort the TL linguistic and stylistic norms. This is in line with the 'relation norm', i.e. the translator has to take into consideration the relationship between the ST elements and the TT elements (ibid.).

\section{DISCOURSE ANALYSIS FOR TRANSLATION}

Discourse analysis is essentially interdisciplinary, combining linguistic, sociocultural and cognitive elements. There are numerous definitions of discourse analysis, perhaps the simplest being the one offered by Brown and Yule (1983: 1) "the analysis of language in use". Discourse analysis has moved away from former approaches that consider translation as an exercise in which translators normally pay attention to grammatical rules and use bilingual dictionaries. Discourse analysis deals with the complex relationships among meaning, culture and language, thereby showing the limitations of bilingual dictionaries as a good translation tool. When translators analyze the text at hand in an attempt to understand it and put a finger on the elements that need special treatment in translation, they have to consider the entire text as a translation unit, not the single word or sentence, thus fixing particular attention to the context, co-text, communicative dimension, pragmatic dimension and semiotic dimension (cf. Hatim and Mason, 1990).

Based on the researchers' own experience and remarks made by other colleagues who are teaching translation at different universities (for example Mohammad Farghal and Jamal Al-Qinai of the University of Kuwait; Said Faiq of the American University of Sharjah, UAE, Mike Hall of the University of Westminster, UK; Raymond Chakhachiro of the University of Western Sydney, Australia; Hasan Ghazala of the University of Umm Al-Qura, Saudi Arabia), one of the difficult problems in translation training is to teach the 
trainee students how to criticize a published and/or unpublished translation academically. In some cases, students busy themselves with finding translation mistakes and merely state that they do not like this translation, thereby suggesting alternatives they believe to be correct. Even worse, sometimes they replace workable translations with bad translations without being able to justify their own versions (cf. Farghal, 2012: 72). Thus, it is important to encourage the trainee student "to perform ST discourse analysis as part of their pre-translation competence before embarking on the process of reformulation into TL" Al-Qinai (2011: 33).

It is worth noting that prior to giving the trainee translators the opportunity to practice by themselves, they may be provided with a reasonable period in which discourse analyses are practiced on published translations with the help of the instructor. At the beginning, however, the approach is almost exclusively teacher-centred. Instructors work hand in hand with their students by providing them with their comments on every single aspect of discourse in an attempt to let them understand the discoursal processes involved in the production of the ST, its function and the translator's role in carrying its sense across language barriers (Lederer, 2007: 21), thus building up self-confidence inside them. As stated above, then, such an exercise can be utilized as a tool for developing translation competence as it heightens students' awareness of the process involved in translating and in the production of translations. Discourse analysis will help them to reflect on what they are doing (cf. Schäffner, 2002; Lederer, 2007; Hall, 2008; Al-Qinai, 2011).

According to the EN-15038 European Quality Standard for Translation Services, paragraph 3.2.3 (2006: 7), the translation evaluator (in our case the translation teacher/instructor), in addition to having the same competences that a qualified translator should have, such as translating competence, linguistic and textual competence, research competence, cultural competence and technical competence, s/he should

a) have "translating experience in the domain under consideration";

b) be as objective as possible; and

c) be able to distinguish between errors and stylistic preference.

Unfortunately, most universities in the Arab world still recruit English teachers to teach translation. In this regard, Al-Qinai (2011: 35), echoing Lederer (2007: 17), rightly comments that such a practice is problematic, because "in order for someone to teach translation, one has to be an expert practitioner in order to understand translation procedures and problems as well as understand what is expected from translators in the job market".

The framework of the linguistic analysis applied here is adopted partially, but not entirely, from Hall (2008). It is based on the analysis of the source and target language texts, operating within two dimensions, the macrocontext, "which has a situational focus", and the microcontext, "which focuses on 
syntactical and lexical factors" (Hall, 2008: 26-27). The approach makes use of comprehensive text analysis, of source and target language texts, genre, text type, register and language function and so other issues. The six areas of concentration provide the essential linguistic components to enable effective comment on overall strategy and the translation process and challenges as well as the identification and annotation of the treatment of particular translation issues that require special attention and application. These areas are:

a) Role of language: register, language function, choice of lexical items and idioms, and grammatical equivalence in translation (such as verb aspect);

b) Aspects of pragmatics: implicature, speech acts, horonifics, politeness strategies;

c) Aspects of textuality: cohesion and thematic progression;

d) Cultural aspects: culture-specific terms, modes of address, names and key references, etc;

e) Stylistic aspects: tropes (i.e. metaphor, simile, metonymy, pun, irony, personification, rhetorical questions, onomatopoeia, oxymoron, etc.) vs. schemes (i.e. parallelism, ellipsis, asyndeton, polysyndeton, anadiplosis, climax, chiasmus, etc.);

f) Strategic aspects: local strategies (i.e. reasoned decisions taken by the translator when facing a particular problem, such as addition, omission, deviation, etc.) vs. global strategies (i.e. the overall strategy taken by the translator before embarking on translating the text).

Due to time and space limitations, these aspects cannot be tackled in detail in this study; therefore, only two aspects would be highlighted, namely the role of language and stylistic aspect. To demonstrate how meaning is directly affected by the sort of language used, let us consider the following example quoted from Choukri's (2000: 175-176; $6^{\text {th }}$ edition) and translated by Bowles (1993: 130-131):

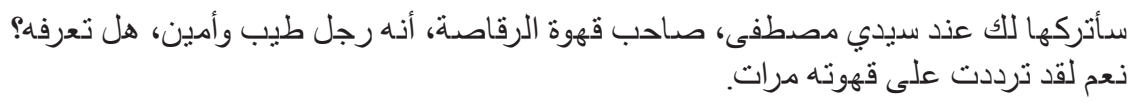

"I'm going to leave the money with Sidi Mustafa at the Café Ragassa. He's reliable. Do you know him?"

"Yes, I go there often."

\section{Comments:}

In the above example, there is a shift in verb aspect from perfective, expressed in the ST by قد ترددت to progressive, expressed by the present simple tense in 
the TT. Such a shift in verb aspect does influence both continuity and time frame. The emphasis in the source text is on the repeated occurrence of the action up to the present, i.e. I've been there several times, while the emphasis is laid on the regularity and frequency of the action as a matter of routine.

To further demonstrate the impact of failing to take into account the role of language, let us consider the following example quoted from Karim 'Abid's (2010: 63) story غرام السيدة (ع) The Passion of Lady A and translated by Eric Winkel (2010: 63):

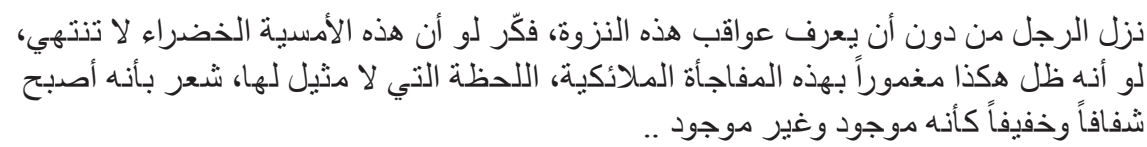

The man got down, not knowing what the consequences of his sudden impulse would be. He thought, if this green evening would not end! If he could stay like this undetected by these unexpected angels! in this moment unlike any other. He was sure he would awake feathery and light, as if he was here, or not here.

\section{Comments:}

1) Here, in the above extract there is a combination of both misuse and inconsistency in the use of punctuation marks - the exclamation mark is followed by a capital letter ' $I f$ ' in the first occurrence, but, later, it is followed by a small letter ' $i n$ '. Further, there is no need for a comma after the introductory verb 'thought' as long as the translator has resorted to indirect speech.

2) There is also a minor grammatical mistake in the use of the adverb of place 'here' in the reported speech whose introductory verb is in the past tense 'was'. In such a case, the adverb of place 'here' should be changed into 'there' as in '... there, or not there'.

3) An example of deviation in و أنه ظل هكذا مغمورا بهذه المفاجئة الملائكية 'if he had remained caught up in such an angelic (or great) surprise' can be identified here. The translator mistakenly has translated it into 'If he could stay like this undetected by these unexpected angels', thus producing a completely different image in the mind of the target reader.

4) As far as the original language function is concerned, it is poetic in so far as it focuses on the message and the selection of language and stylistic elements (cf. Burton, 1980: 175). However, the language in the TT loses most of its stylistic elements, thereby affecting its poetic function.

To demonstrate the impact of failing to reflect certain stylistic features in authentic translation practice, let us consider the following example quoted from Greene's (1980: 9) The Bomb Party and translated into Arabic by 'Ali Sālih (1989: 7): 
I think that I used to detest Doctor Fischer more than any other man I have known just as I loved his daughter more than any other woman.

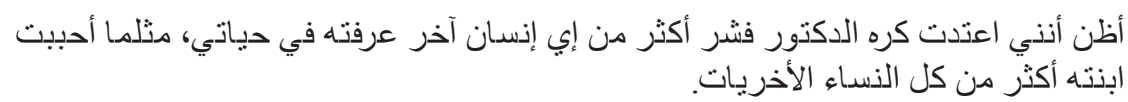

\section{Comments:}

1) Here, it is apparent that the original writer uses parallelism: (I used to detest Doctor Fischer more than any other man/I loved his daughter more than any other woman). Such parallel structures need to be reflected in the TT, provided that such a reflection would not distort the TL linguistic and stylistic norms (see below).

2) Further, Greene introduces two antonyms, i.e. 'detest' vs. 'love' and 'man' vs. 'woman' in a very short extract. As these antonyms fall in parallel structures, they acquire stylistic features that need to be maintained in the TT. Given these stylistic features full consideration, the translator could have produced a rendering as in:

$$
\text { أظبّ أنتي كنت أكثر من أكره الدكتور فشر أكثر في العالم. من أي رجل آخر عرفته بحياتي، تماماً مثلما كنت }
$$

Here, an attempt is also made to deliberately use antonyms in our suggested rendering: أكره vs. أحبّ and رجل vs. أحره It is also worth noting that the main reason for opting for the lexical item كره 'i.e. hate', rather than بغض 'i.e. hate + hostility' or مقت 'i.e. hate + censure' is to make up for the alliteration utilized by the original writer, i.e. detest Doctor.

Having obtained the required experience, student translators are then asked to do the task by themselves, thus the approach at the end of the course will turn into a student-centred approach.

\section{CONCLUSION}

In this paper, the traditional methodologies of teaching translation that focus on text-typologies have been reviewed in an attempt to propose a comprehensive qualitative approach that involves a set of interdisciplinary skills with a view to improving the trainee translators' level.

Due primarily to the nature of the translation process itself, some extra skills and practice, comprising discourse analysis, revision, editing, documentation, text presentation, desktop publishing and the like need to be given to trainee translators. As such, special attention needs be paid to the minimalist approach, revision vs. editing and discourse analysis. It has been shown that such an approach is only effective and valid when students have, or 
acquire through training, a good command in source- and target languages as well as developing a certain level of cultural competence.

The approach proposed in the current study is a combination of both teacher- and student-centred approaches. As the validity of the approach relies partially on teachers' competence and skills in teaching translation, it is strongly recommended that universities in Iraq, and possibly in the Arab world, need to recruit expert practitioners to teach translation. Expert practitioners can effectively contribute to the teaching of translation, alongside academics with a good grasp of the theoretical knowledge of the subject. This is because bilingual teachers, whatever communicative competence they have in both languages, cannot understand translation procedures and problems as well as understand what is expected from translators in realistic situations. Further, it has been shown that discourse analysis, as an approach to text analysis, provides both translation students and translation teachers with resources for making reasoned decisions objectively on the one hand, and for justifying these decisions on the other. Discourse analysis can be applied in translation to all text types: literary, scientific, legal, religious and so on. Translation teachers/ instructors will work hand in hand with their students by providing them with their comments on every single aspect of discourse in an attempt to let them understand the discoursal processes involved in the production of the source text, its function and the translator's role in carrying its sense across language barriers, thus building up self-confidence inside them.

\section{REFERENCES}

Almanna, A. (2013). Quality in the Translation of Narrative Fictional Texts from Arabic into English for the Purposes of Publication: Towards a Systematic Approach to (Self-) assessing the Translation Process, unpublished Ph.D thesis: University of Durham.

Al-Qiniai, J. (2011a). "Training Tools for Translators and Interpreters", JJMLL, Vol. 3 (1), pp. 19-38.

As-Safi, A. and Ash-Sharifi, I (1997). "Naturalness in Literary Translation", Babel, Vol. 43 (1), pp. 60-75.

Brown, G. and Yule, G. (1983). Discourse Analysis Cambridge: Cambridge University Press.

Burton, D. (1980). Dialogue and Discourse: A Sociolinguistic Approach to Modern Drama Dialogue and Naturally Occurring Conversation. London/ Boston/Henley: Routledge and Kegan Paul.

Chakhachiro, R. (2005). "Revision for Quality", Perspectives Studies in Translatology, Vol. 13 (3), pp. 225-238.

Chesterman, A. (2000). Memes of Translation: The Spread of Ideas in Translation Theory. Amsterdam/Philadelphia: John Benjamins.

Farghal, M. (2012). Advanced Issues in Arabic-English Translation Studies. Kuwait: Kuwait University Press. 
Graham, J. D. (1983). "Checking, Revision and Editing”. In Picker. C. (ed.) The Translator's Handbook. London: Aslib, pp. 99-105.

Greene, G. (1980). The Bomb Party. Harmondsworth: Penguin Books.

Hall. M. F. (2008). Discourse Analysis of Fictional Dialogue in Arabic to English Translation, unpublished Ph.D thesis: University of London.

Hatim, B. and I. Mason.1990. Discourse and the Translator. London: Longman. Kingscott, G. (1995). "The impact of Technology and the Implications for Teaching”. In C. Dollerup and V. Appel (eds.) Teaching Translation and Interpreting 3 New Horizon. Papers from the Third Language International Conference Elsinore, Denmark, pp. 293-300.

Kiraly, D. 2000. A Social Constructivist Approach to Translator Education; Empowerment from Theory to Practice. Manchester, UK \& Northampton MA: St. Jerome Publishing.

Lederer, M. (2007). "Can Theory Help Translator and Interpreter Trainers and Trainees". The Interpreter and the Translator Trainer, Vol. 1 (1), pp. 15-35. Mossop, B. (2007a). Revising and Editing for Translators. Manchester: St. Jerome Publishing.

Olvera-Lobo, M. D. et al (2005). "Translator Training and Modern Market Demands". Perspective: Studies in Translatology, Vol. 13 (2), pp. 132-134.

Pym, A. (2003). "Redefining Translation Competence in an Electronic Age: In Defence of a Minimalist Approach". Meta, Vol. 48 (4), pp. 481-497.

Sālih, A. (trans.) (1989). حفلة القنبلة Haflat al-Qunbulah. Baghdad: Dār al-Shū'ūn al-Thaqāfīa al-‘amah.

Schäffner, C. (ed.) (2002). The Role of Discourse Analysis for Translation and in Translator Training. Clevedon: Multilingual Matters Ltd.

Thornbury, S. (2006). An A-Z of ELT. Oxford: Macmillan.

Ulrych, M. (1995). "Real-World Criteria in Translation Pedagogy". In C. Dollerup and V. Appel (eds.) Teaching Translation and Interpreting 3 New Horizon. Papers from the Third Language International Conference Elsinore, Denmark, pp. 252-259.

Venuti, L. (1998). The Scandals of Translation. London: Routledge.

Williams, J. and Chesterman, A. (2002). The Map. Manchester: St. Jerome Publishing.

\section{ARABIC SOURCE TEXTS AND TRANSLATIONS:}

$$
\text { كريم عبد (2010) ليالي السيد سلمان. دار السياب: لندن }
$$

Translated by Eric Winkel (2010; bilingual edition) as Nights of Mr Salman. London: Sayyab Books Ltd.

$$
\text { دار الساقي. شكري (2000) الخبز الحافي: سيرة ذاتية روائية: 1935-1956 (الطبعة السادسة). لندن: }
$$

Translated by Paul Bowles (1993) as For Bread Alone. London: Saqi Books. 